\title{
Synthesis, Structures, and Catalytic Reactivity of Bis(N-Heterocyclic Carbene) Supported Diphenyldiazomethane and 1-Azidoadamantane Complexes of Nickel
}

Nicole D. Harrold,* Amanda R. Corcos,ł and Gregory L. Hillhouse $\perp$

Gordon Center for Integrative Science, Department of Chemistry, The University of Chicago, 929 East 57th Street, Chicago, Illinois, 60637, USA

* Email: nharrold@uchicago.edu 


\section{Abstract.}

Diphenyldiazomethane reacts with $\mathrm{Ni}(\mathrm{NHC})_{2}(\mathbf{1}, \mathrm{NHC}=\mathrm{N}$-heterocyclic carbene $)$ to afford complexes of the type (NHC) ${ }_{2} \mathrm{Ni}\left(\kappa^{1}-\mathrm{N}_{2} \mathrm{CPh}_{2}\right)$ (3) in which the diazoalkane ligand is bound to the metal in an end-on $\kappa^{1}$ fashion. Additionally, 1-IMes (IMes $=1,3-$ bis(2,4,6trimethylphenyl)imidazol-2-ylidene) reacts with 1-azidoadamantane ( $\left.\mathrm{N}_{3} \mathrm{Ad}\right)$ to produce (IMes) ${ }_{2} \mathrm{Ni}\left(\eta^{2}-\mathrm{N}_{3} \mathrm{Ad}\right)(4)$ in which the azide ligand is bound to the metal in a side-bound $\eta^{2}$ fashion. While thermolysis of $\mathbf{3}$ and $\mathbf{4}$ does not induce $\mathrm{N}_{2}$ loss to form terminal carbenes and imidos, respectively, (IMes) ${ }_{2} \mathrm{Ni}\left(\kappa^{1}-\mathrm{N}_{2} \mathrm{CPh}_{2}\right)$ (3-IMes) reacts with olefins at elevated temperatures to give cyclopropane products in excellent yields. Either 3-IMes or 1-IMes can also perform this reaction catalytically with a 1:1 ratio of diphenyldiazomethane to olefin. An olefin activation mechanism is proposed to explain the cyclopropanation reaction.

\section{GRAPHICAL ABSTRACT.}

Complexes of type $(\mathrm{NHC})_{2} \mathrm{Ni}\left(\kappa^{1}-\mathrm{N}_{2} \mathrm{CPh}_{2}\right)$ (3), in which diphenyldiazomethane is bound to an $N$-heterocyclic carbene-supported nickel center in an unusual $\kappa^{1}$ end-on fashion, react with olefins at elevated temperatures to give cyclopropane products in excellent yields. 3-IMes or 1IMes can also perform this reaction catalytically with an efficient 1:1 ratio of diphenyldiazomethane to olefin.

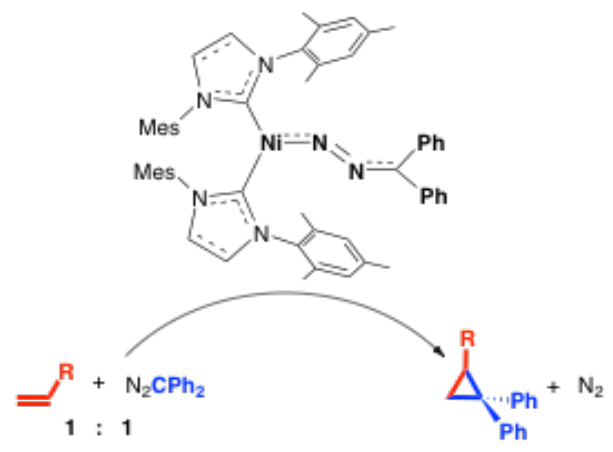




\section{KEYWORDS.}

1. Nickel

2. $N$-heterocyclic carbene (NHC)

3. Catalysis

4. Cyclopropanation

5. Diazoalkane

6. Organoazide

\section{INTRODUCTION.}

Diazoalkanes are commonly used precursors for the synthesis of metallacarbenes, ${ }^{[1-3]}$ which in turn are versatile chemical moieties capable of olefin cyclopropanation, $\mathrm{C}-\mathrm{H}$ activation, and other reactions. ${ }^{[4-12]}$ While $\mathrm{N}_{2}$ elimination from diazoalkanes is generally facile upon reaction with metal complexes, the isolation and characterization of metal-bound diazoalkane adducts is possible and has yielded a plethora of complexes spanning multiple coordination modes. ${ }^{[6,7,13,14]}$ Five coordination modes are possible for a diazoalkane moiety bound to a single transition metal center (Chart 1): $\kappa^{1}-\mathrm{N}$ end-on coordination involving the terminal $\mathrm{N}$ (type A), ${ }^{[15-}$ ${ }^{22]} \eta^{2}-\mathrm{N}, \mathrm{N}$ side-on (type $\left.\mathbf{B}\right),{ }^{[23-28]} \eta^{2}-\mathrm{C}, \mathrm{N}$ side-on (type $\mathbf{C}$ ), $\kappa^{2}-\mathrm{C}, \mathrm{N}$ metallacyclic (type $\mathbf{D}$ ), and $\kappa^{1}-\mathrm{C}$ coordination (type $\mathbf{E}$ ). Coordination of a diazoalkane to more than one metal atom is also possible. $^{[29]}$

Several limiting electronic configurations for the $\kappa^{1}-\mathrm{N}$ binding configuration (A) are shown in Chart 2. In configuration $\mathbf{A}_{\mathbf{1}}$, the diazoalkane ligand serves as a neutral 2-electron donor with a dative interaction between the terminal nitrogen and the metal center. The diazoalkane ligands in configurations $\mathbf{A}_{\mathbf{2}}$ (singly bent) and $\mathbf{A}_{3}$ (doubly bent) are bound to the metal center through two covalent bonds $(\sigma+\pi)$. Configuration $\mathbf{A}_{4}$ features two covalent bonds and one dative bond.

Chart 1. Diazoalkane binding modes to a single metal center.

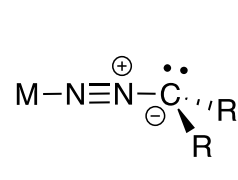

A

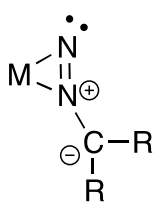

B

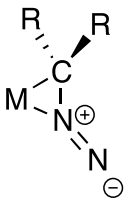

C

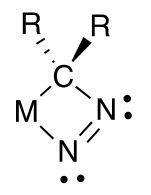

D

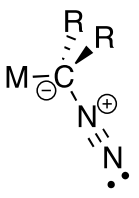

E 
Chart 2. Electronic configurations for a $\kappa^{1}-\mathrm{N}$ end-on diazoalkane bound to a single metal center.

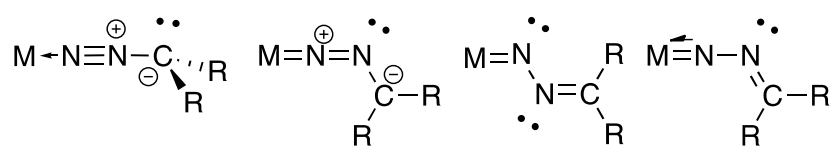

$\begin{array}{llll}A_{1} & A_{2} & A_{3} & A_{4}\end{array}$

In a similar manner, organoazides are often used as imido precursors, ${ }^{[30-32]}$ which can undergo group transfer and $\mathrm{C}-\mathrm{H}$ amination after reacting with a metal center to induce loss of $\mathrm{N}_{2}{ }^{[33-37]}$ There are several possible coordination modes for organoazides to bind to a metal center. In the few instances where these complexes are stable enough for isolation, the ligand is usually bound as a diazenylimido $\left(\mathrm{RN}_{3}{ }^{2-} \text { as } \mathbf{F}, \mathbf{G} \text {, or } \mathbf{H} \text { in Chart } 3\right)^{[38-42]}$ or as a neutral $\mathrm{RN}_{3}$ through the $\alpha$ or $\gamma$ N-atoms (I and $\mathbf{J}) .^{[43-45]}$

Chart 3. Common organoazide binding modes to a metal center.

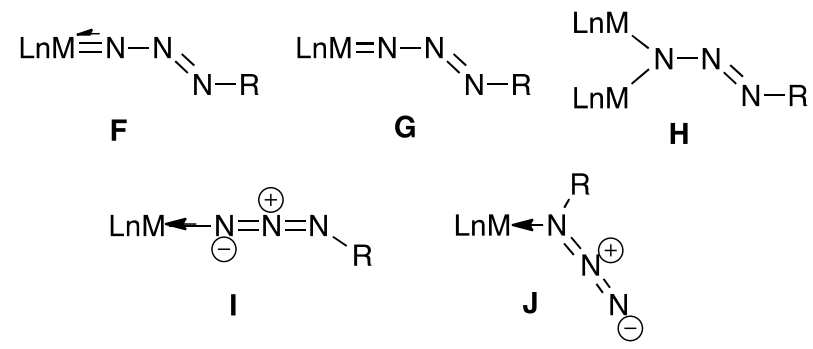

Herein we report the synthesis, structures, and reactivity of several new bis(Nheterocyclic carbene) (NHC) supported diphenyldiazomethane complexes of $\mathrm{Ni}$ in which the diazo ligand is bound to the metal in a $\kappa^{1}$ end-on fashion (A). These complexes mediate cyclopropane formation in high yields from stoichiometric and catalytic 1:1 mixtures of diazoalkanes and olefins, whereas typical cyclopropanation catalysis requires an excess of olefin for good selectivity and high yields. It is proposed that catalysis for this system occurs without the intermediacy of a metallacarbene. The synthesis and reactivity of a new bis(NHC) supported organoazide complex of $\mathrm{Ni}$, in which the azide ligand is bound to the metal in an $\eta^{2}$-fashion, is also reported and its reactivity discussed. 


\section{MATERIALS AND METHODS.}

2.1. General Considerations. Unless stated otherwise, all operations were performed in an MBraun Lab Master dry box under an atmosphere of purified nitrogen. Anhydrous diethyl ether $\left(\mathrm{Et}_{2} \mathrm{O}\right)$ and tetrahydrofuran (THF) were purchased from Fischer, stirred over sodium metal, and filtered through activated alumina. ${ }^{[46]}$ Pentane was purchased from Sigma Aldrich and dried by passage through activated alumina and Q-5 columns. $\mathrm{C}_{6} \mathrm{D}_{6}$ was purchased from Cambridge Isotope Laboratories, degassed by freeze-pump-thaw cycles, and dried over $\mathrm{CaH}_{2}$ or activated 4 $\AA$ molecular sieves. Celite, alumina, and $4 \AA$ molecular sieves were activated by evacuation overnight at $180{ }^{\circ} \mathrm{C} . \mathrm{N}_{2} \mathrm{CPh}_{2},{ }^{[47]} \mathrm{N}_{3} \mathrm{Ad},{ }^{[48-50]}$ IMes, ${ }^{[51-53]}$ SIMes, ${ }^{[51]} \mathrm{IPr}^{[51,52,54]}$ and $\mathrm{Ni}(\mathrm{IMes})_{2}^{[55]}$ were prepared according to the literature. All other chemicals were used as received. Please note: caution should used when conducting photolytic and thermolytic experiments on diazoalkane and organoazide species, for such species have the potential to be explosive. Due to the small scale on which these reactions were performed and the low temperatures utilized, all reactions performed here are deemed safe.

2.2. Instruments. Elemental analyses were performed by Midwest Microlab (Indianapolis,

IN). ${ }^{1} \mathrm{H}$ NMR spectra were recorded on a Bruker $500 \mathrm{MHz}$ NMR spectrometer and reported with reference to solvent resonance (for example, residual $\mathrm{C}_{6} \mathrm{D}_{5} \mathrm{H}$ in $\mathrm{C}_{6} \mathrm{D}_{6}$ at $7.16 \mathrm{ppm}$ ). Infrared data (Fluorolube or Nujol mulls, $\mathrm{CaF}_{2}$ or $\mathrm{KBr}$ plates, respectively) were measured using a Nicolet Nexus 670 FT-IR.

\subsection{Synthesis.}

2.3.1. Preparation of $(\mathrm{NHC})_{2} \mathrm{Ni}\left(\kappa^{1}-\mathrm{N}_{2} \mathrm{CPh}\right)$ (3). A typical procedure is given for the synthesis of 3-IMes. A cold $\left(-35^{\circ} \mathrm{C}\right)$ solution of $145 \mathrm{mg}(750 \mathrm{mmol}) \mathrm{N}_{2} \mathrm{CPh}_{2}$ in $5 \mathrm{~mL}$ diethyl ether was added to a cold stirring solution of $500 \mathrm{mg}$ (750 mmol) Ni(IMes) 2 (1-IMes) in $10 \mathrm{~mL}$ diethyl ether. The reaction was stirred at room temperature for 1 hour after which the reaction mixture was reduced to dryness. The resulting solids were then washed with cold hexanes $(3 \times 5 \mathrm{~mL})$. The resulting orange red solids were dried under vacuum for 2 hours. The characterization data for 3-IMes, 3-SIMes, and 3-IPr are given below. All complexes are stable in the freezer (-35 ${ }^{\circ} \mathrm{C}$ ) for up to 6 months but degrade if left at room temperature or exposed to light for more than one week. 
2.3.1.1. (IMes) ${ }_{2} \mathrm{Ni}\left(\kappa^{1}-\mathrm{N}_{2} C P h_{2}\right)$ (3-IMes). Yield: $620 \mathrm{mg}(96 \%) .{ }^{1} \mathrm{H}$ NMR (298 K, 500.13 $\mathrm{MHz}, \mathrm{C}_{6} \mathrm{D}_{6}$ ): $\delta 7.68$ (d, 4H, o- $\mathrm{C}_{6} \mathrm{H}_{6}$ ), 7.19 (t, 4H, m- $\mathrm{C}_{6} \mathrm{H}_{6}$ ), 6.86 (t, 2H, p- $\left.\mathrm{C}_{6} \mathrm{H}_{6}\right), 6.69$ (s, 8H, $\mathrm{C}_{6} \mathrm{H}_{2}$ ), 6.02 (s, 4H, $\mathrm{NC}_{2} \mathrm{H}_{2} \mathrm{~N}$ ), 2.28 (s, $\left.12 \mathrm{H}, \mathrm{C}_{6} \mathrm{H}_{2}\left(\mathrm{CH}_{3}\right)_{3}\right), 1.87$ (s, 24H, $\left.\mathrm{C}_{6} \mathrm{H}_{2}\left(\mathrm{CH}_{3}\right)_{3}\right) ;{ }^{13} \mathrm{C}\left\{{ }^{1} \mathrm{H}\right\}$ NMR (298 K, 125.76 MHz, $\left.\mathrm{C}_{6} \mathrm{D}_{6}\right): \delta$ 199.8, 138.8, 138.4, 137.7, 136.4, 129.8, 128.3, 125.8, 123.6, 121.7, 21.9, 18.9. IR (Nujol, KBr): 3153 (m), 2915 (m), 2041 (s), 1703 (s), 1608 (s), 1560 (s), 1487 (s), 1447 (s), 1405 (s) cm ${ }^{-1}$. Anal. Calcd. for $\mathrm{C}_{55} \mathrm{H}_{58} \mathrm{NiN}_{6}$ : C, 76.75; H, 6.78; N, 9.75. Found: $\mathrm{C}, 74.71 ; \mathrm{H}, 6.30 ; \mathrm{N}, 9.06$. Please note these values are not within the standard range due to (unavoidable) decomposition of the complex during shipment to the EA facilities. All other characterizations and catalytic reactions presented here were performed with freshly-made (nondecomposed) materials.

2.3.1.2. (SIMes) ${ }_{2} \mathrm{Ni}\left(\kappa^{1}-\mathrm{N}_{2} \mathrm{CPh}_{2}\right)$ (3-SIMes). Yield: $595 \mathrm{mg}$ (92\%). ${ }^{1} \mathrm{H}$ NMR (298 K, $\left.500.13 \mathrm{MHz}, \mathrm{C}_{6} \mathrm{D}_{6}\right): \delta 7.71\left(\mathrm{~d}, 4 \mathrm{H}, \mathrm{o}_{6} \mathrm{C}_{6} \mathrm{H}_{6}\right), 7.33\left(\mathrm{t}, 4 \mathrm{H}, \mathrm{m}-\mathrm{C}_{6} \mathrm{H}_{6}\right), 6.99\left(\mathrm{t}, 2 \mathrm{H}, \mathrm{p}-\mathrm{C}_{6} \mathrm{H}_{6}\right), 6.89(\mathrm{~d}$, $\left.8 \mathrm{H}, \mathrm{C}_{6} \mathrm{H}_{3}\right), 6.76\left(\mathrm{t}, 4 \mathrm{H}, \mathrm{C}_{6} \mathrm{H}_{3}\right), 3.15\left(\mathrm{~s}, 8 \mathrm{H}, \mathrm{NC}_{2} \mathrm{H}_{4} \mathrm{~N}\right), 6.69\left(\mathrm{~s}, 8 \mathrm{H}, \mathrm{C}_{6} \mathrm{H}_{2}\right), 2.27(\mathrm{~s}, 12 \mathrm{H}$, $\left.\mathrm{C}_{6} \mathrm{H}_{2}\left(\mathrm{CH}_{3}\right)_{3}\right), 1.98$ (s, 24H, $\left.\mathrm{C}_{6} \mathrm{H}_{2}\left(\mathrm{CH}_{3}\right)_{3}\right) ;{ }^{13} \mathrm{C}\{1 \mathrm{H}\}$ NMR (298 K, $\left.125.76 \mathrm{MHz}, \mathrm{C}_{6} \mathrm{D}_{6}\right): \delta$ 138.9, 138.6, 137.2, 136.7, 130.3, 125.9, 121.8, 51.8, 21.9, 18.8. IR (Nujol, KBr): 2810 (m), 2043 (s), 1713 (s), 1606 (s), 1563 (s), 1487 (s), 1448 (s), 1410 (s) cm ${ }^{-1}$.

2.3.1.3. $(\mathrm{IPr})_{2} \mathrm{Ni}\left(\kappa^{1}-\mathrm{N}_{2} \mathrm{CPh}\right.$ ) (3-IPr). Yield: $631 \mathrm{mg}(82 \%) .{ }^{1} \mathrm{H}$ NMR (298 K, 500.13 MHz, $\left.\mathrm{C}_{6} \mathrm{D}_{6}\right): \delta 7.65$ (d, 4H, o- $\mathrm{C}_{6} \mathrm{H}_{6}$ ), $7.58\left(\mathrm{t}, 4 \mathrm{H}, \mathrm{m}-\mathrm{C}_{6} \mathrm{H}_{6}\right), 7.22$ (t, 2H, p- $\left.\mathrm{C}_{6} \mathrm{H}_{6}\right), 6.04(\mathrm{~s}, 4 \mathrm{H}$, $\mathrm{NC}_{2} \mathrm{H}_{2} \mathrm{~N}$ ), 2.23 (m, 8H, $\left.\mathrm{CH}\left(\mathrm{CH}_{3}\right)_{2}\right), 1.31$ (d, 24H, $\left.\mathrm{CH}\left(\mathrm{CH}_{3}\right)_{2}\right), 1.07$ (d, $\left.24 \mathrm{H}, \mathrm{CH}\left(\mathrm{CH}_{3}\right)_{2}\right) ;{ }^{13} \mathrm{C}\left\{{ }^{1} \mathrm{H}\right\}$ NMR (298 K, $125.76 \mathrm{MHz}, \mathrm{C}_{6} \mathrm{D}_{6}$ ): $\delta$ 204.8, 142.8, 137.4, 137.3, 134.3, 127.8, 126.4, 126.3, 125.8, 123.6, 121.7, 21.9, 18.9, 18.7. IR (Nujol, KBr): 2805 (m), 2042 (s), 1713 (s), 1605 (s), 1559 (s), 1484 (s), 1448 (s), 1410 (s) $\mathrm{cm}^{-1}$.

2.3.2. Stoichiometric Procedure for Formation of Cyclopropane. A typical procedure is given for the formation of 1,2-diphenyl-2-butylcyclopropane. In a $25 \mathrm{~mL}$ glass bomb equipped with a stir bar was loaded 3-IMes (100 mg, $0.116 \mathrm{mmol}$ ) and $10 \mathrm{~mL}$ toluene. To the solution was added 1-hexene (9.8 mg, $0.116 \mathrm{mmol}$ ) dissolved in $1 \mathrm{~mL}$ of toluene at $22^{\circ} \mathrm{C}$. The solution remained red in color upon addition. Upon heating (2 hours, $60^{\circ} \mathrm{C}$ ) the solution turned dark purple in color. After completion the solution was exposed to air and filtered through celite. The filtrate was then passed through a short $\mathrm{SiO}_{2}$ column (1:1 hexanes: diethyl ether). The yellow band was collected and dried under reduced pressure for 2 hours to afford pure cyclopropane. The characterization data for cyclopropane products are given below. 
2.3.2.1. 1,2-diphenyl-2-butylcyclopropane. Yield: $26.1 \mathrm{mg}$ (90\%). ${ }^{1} \mathrm{H}$ NMR (298 K, $\left.500.13 \mathrm{MHz}, \mathrm{CDCl}_{3}\right): \delta 7.35$ - $7.19(\mathrm{~m}, 10 \mathrm{H}, \mathrm{Ph}), 1.61\left(\mathrm{~m}, 1 \mathrm{H}, \mathrm{C}_{4} \mathrm{H}_{9}\right), 1.43\left(\mathrm{~m}, 2 \mathrm{H}, \mathrm{C}_{4} \mathrm{H}_{9}\right), 1.32$ (m, $1 \mathrm{H}, \mathrm{C}_{4} \mathrm{H}_{9}$ ), 1.25 (4 line, $1 \mathrm{H}, \mathrm{CH}_{2}, \mathrm{JHH}=8.8,4.6 \mathrm{~Hz}$ ), 1.19 (4 line, $1 \mathrm{H}, \mathrm{CH}_{2}, \mathrm{JHH}=4.6,6.3$ $\mathrm{Hz}), 0.85$ (t, 3H, $\left.\mathrm{C}_{4} \mathrm{H}_{9}\right), 0.74\left(\mathrm{~m}, 1 \mathrm{H}, \mathrm{C}_{4} \mathrm{H}_{9}\right) ;{ }^{13} \mathrm{C}\left\{{ }^{1} \mathrm{H}\right\}$ NMR (298 K, $\left.125.76 \mathrm{MHz}, \mathrm{CDCl}_{3}\right): \delta$ 130.8, 128.6, 126.2, 125.7, 35.4, 31.8, 29.9, 26.6, 22.7, 21.1, 11.7; GC/MS (m/z): $250\left(\mathrm{M}^{+}\right), 193$ (M-Bu), $165\left(\mathrm{Ph}_{2} \mathrm{C}^{+}-\mathrm{H}\right)$.

2.3.2.2. 1,1-diphenyl-2,2,3-trimethylcyclopropane. Yield: $24.7 \mathrm{mg}$ (90\%). ${ }^{1} \mathrm{H}$ NMR (298 K, $500.13 \mathrm{MHz}, \mathrm{CDCl}_{3}$ ): $\delta 7.27-6.95$ (m, 10H, Ph), 1.34 (s, 3H, $\mathrm{CH}_{3}$ ), 1.02 (s, 3H, $\mathrm{CH}_{3}$ ), 1.00 (s, 3H, $\left.\mathrm{CH}_{3}\right) ;{ }^{13} \mathrm{C}\left\{{ }^{1} \mathrm{H}\right\}$ NMR (298 K, $\left.125.76 \mathrm{MHz}, \mathrm{CDCl}_{3}\right): \delta 146.1,129.2,128.2,128.1,127.4$, 126.2, 126.1, 46.0, 33.7, 26.4, 22.4, 15.2; GC/MS (m/z): $236\left(\mathrm{M}^{+}\right), 221\left(\mathrm{M}^{+}-\mathrm{Me}\right), 143\left(\mathrm{M}^{+}-\mathrm{Me}-\right.$ $\mathrm{Ph})$.

2.3.2.3. 7,7-diphenylbicyclo[4.1.0]heptane. Yield: $24.8 \mathrm{mg}$ (86\%). ${ }^{1} \mathrm{H}$ NMR (298 K, $\left.500.13 \mathrm{MHz}, \mathrm{CDCl}_{3}\right): \delta 7.35-7.01(\mathrm{~m}, 10 \mathrm{H}, \mathrm{Ph}), 2.30-0.62\left(\mathrm{~m}, 10 \mathrm{H}, \mathrm{C}_{4} \mathrm{H}_{8}\right) ;{ }^{13} \mathrm{C}\{1 \mathrm{H}\} \mathrm{NMR}$ (298 K, $125.76 \mathrm{MHz}, \mathrm{CDCl}_{3}$ ): $\delta$ 149.7, 140.1, 131.6, 128.5, 127.8, 36.2, 25.2, 22.3, 21.4; GC/MS (m/z): $250\left(\mathrm{M}^{+}\right), 205\left(\mathrm{M}^{+}\right.$-C3H6), $165\left(\mathrm{Ph}_{2} \mathrm{C}^{+}-\mathrm{H}\right)$.

2.3.2.4. 1,1-diphenyl-2-butyl-3-methylcyclopropane. Yield: $23.2 \mathrm{mg}$ (80\%). ${ }^{1} \mathrm{H}$ NMR (298 K, $500.13 \mathrm{MHz}, \mathrm{CDCl}_{3}$ ): $\delta 7.28-7.01$ (m, 10H, Ph), $1.64-1.39$ (m, 7H), $1.08-1.04$ (m, 3H), $0.96-0.91$ (m, 2H); ${ }^{13} \mathrm{C}\left\{{ }^{1} \mathrm{H}\right\}$ NMR (298 K, $\left.125.76 \mathrm{MHz}, \mathrm{CDCl}_{3}\right): \delta 147.4,147.3,129.7$, 129.5, 128.2, 128.1, 126.4, 126.1, 56.0, 35.1, 34.1, 24.6; GC/MS (m/z): 250 (M+), 207 (M-Pr).

2.3.3. Catalytic Procedure for 1,2-diphenyl-2-butylcyclopropane. In a $25 \mathrm{~mL}$ glass bomb equipped with a stir bar was loaded Ni(IMes) 2 (1-IMes) (205 mg, $0.238 \mathrm{mmol}, 20 \mathrm{~mol} \%$ ) and 10 $\mathrm{mL}$ toluene. To the solution was added 1-hexene (100 mg, $1.19 \mathrm{mmol})$ and $\mathrm{N}_{2} \mathrm{CPh}_{2}(231 \mathrm{mg}$, $1.19 \mathrm{mmol}$ ) dissolved in $1 \mathrm{~mL}$ of toluene at $22^{\circ} \mathrm{C}$. The solution remained red in color upon addition. Upon heating ( 12 hours, $60^{\circ} \mathrm{C}$ ) the solution turned dark purple in color. After completion the solution was exposed to air and filtered through celite. The filtrate was then passed through a short $\mathrm{SiO}_{2}$ column (1:1 hexanes: diethyl ether). The yellow band was collected and dried under reduced pressure for 2 hours to afford pure cyclopropane (250 mg, 84\%).

2.3.4. Preparation of (IMes) ${ }_{2} \mathrm{Ni}\left(\eta^{2}-\mathrm{N}_{3} \mathrm{Ad}\right)$ (4). A cold, $5 \mathrm{~mL}$ THF solution of $\mathrm{N}_{3} \mathrm{Ad}$ (26.6 $\mathrm{mg}, 0.150 \mathrm{mmol}$ ) was added to a cold, $10 \mathrm{~mL}$ solution of 1-IMes (100 $\mathrm{mg}, 0.150 \mathrm{mmol}$ ). The solution was stirred at room temperature for 1 hour. The resulting solution was reduced to dryness under reduced pressure. The crude light brown solid was then washed with cold hexanes (2 
x $5 \mathrm{~mL}$ ) resulting in a light tan solid, from which crystals were grown after concentration in cold toluene and layering with hexanes (68 mg, 55\%). This complex is stable in the freezer $\left(-35^{\circ} \mathrm{C}\right)$ for up to 3 months but degrades if left at room temperature or exposed to light for more than one week. ${ }^{1} \mathrm{H}$ NMR (298 K, $500.13 \mathrm{MHz}, \mathrm{C}_{6} \mathrm{D}_{6}$ ): $\delta 6.69$ (s, 8H, $\mathrm{C}_{6} \mathrm{H}_{2}$ ), 6.09 (s, 4H, $\mathrm{NC}_{2} \mathrm{H}_{2} \mathrm{~N}$ ), 2.29 (s, 12H, $\left.\mathrm{C}_{6} \mathrm{H}_{2}\left(\mathrm{CH}_{3}\right)_{3}\right), 2.23$ (s, 4H, Ad), 2.19 (s, 6H, $\left.\mathrm{C}_{6} \mathrm{H}_{2}\left(\mathrm{CH}_{3}\right)_{3}\right), 2.03$ (s, $12 \mathrm{H}, \mathrm{C}_{6} \mathrm{H}_{2}\left(\mathrm{CH}_{3}\right)_{3}$ ), 1.91 (d, 5H, Ad), 1.76 (d, 5H, Ad), 1.41 (s, 2H, Ad). ${ }^{13} \mathrm{C}\left\{{ }^{1} \mathrm{H}\right\}$ NMR (298 K, $\left.125.76 \mathrm{MHz}, \mathrm{C}_{6} \mathrm{D}_{6}\right)$ : $\delta$ 204.3, 137.7, 137.2, 137.1, 135.1, 132.7, 128.5, 126.4, 118.0, 51.0, 38.7, 36.5, 2.4, 21.9, 17.2, 17.1; IR (Nujol, KBr): 1349 (m), 1283 (w), 1181 (s), 1149 (s), 1116 (s), 1099 (s), 1078 (m), 1044 (w), 1022 (m), 938 (m), 898 (w), 845 (s), 813 (s), 783 (s), 724 (w), 686 (s), 657 (s), 582 (m), 496 (s) $\mathrm{cm}^{-1}$. Anal. Calcd for $\mathrm{C}_{52} \mathrm{H}_{63} \mathrm{NiN}_{7}$ : C, 73.93; H, 7.52; N, 11.61. Found: C, 71.40; H, 7.37; N, 10.05. Please note these values are not within the standard range due to (unavoidable) decomposition of the complex during shipment to the EA facilities. All other characterizations and catalytic reactions presented here were performed with freshly-made (non-decomposed) materials.

2.3.5. Synthesis of (IMes) ${ }_{2} \mathrm{Ni}\left(\eta^{2}-\mathrm{C}_{6} \mathrm{H}_{12}\right)$ (5). A solution of 1-IMes (10.0 mg) was put in an NMR tube and dissolved in $\mathrm{C}_{6} \mathrm{D}_{6}$. To the NMR tube was added 1-hexene (28 mg, $0.33 \mathrm{mmol}$ ) via syringe. Immediately the color changed from purple to red. The NMR was taken immediately. The NMR tube was heated at $60{ }^{\circ} \mathrm{C}$ and no visible or spectroscopic change occurred even after prolonged (12 h) in the oil bath. The ${ }^{1} \mathrm{H}$ NMR (shown below) of complex 5 was obtained in a $\mathrm{C}_{6} \mathrm{D}_{6}$ solution with excess ( 40 equivalents) 1-hexene. Due to the large excess of 1-hexene the ${ }^{13} \mathrm{C}$ shifts of $\mathbf{5}$ could not be obtained. Attempts to isolate complex $\mathbf{5}$ on a preparatory scale were unsuccessful as 1-hexene dissociates from the metal upon solvent removal. ${ }^{1} \mathrm{H}$ NMR (298 K, $500.13 \mathrm{MHz}, \mathrm{C}_{6} \mathrm{D}_{6}$ ): $\delta 6.72$ (s, 8H, $\mathrm{C}_{6} \mathrm{H}_{2}$ ), $6.72(\mathrm{~m}, 1 \mathrm{H}, 1-\mathrm{hex}), 6.69$ (m, 1H, 1-hex), 6.33 (m, 1H, 1-hex), 6.11 (s, 4H, $\mathrm{NC}_{2} \mathrm{H}_{2} \mathrm{~N}$ ), 2.26 (s, $24 \mathrm{H}, \mathrm{C}_{6} \mathrm{H}_{2}\left(\mathrm{CH}_{3}\right)_{3}$ ), 2.20-1.96 (m, 9H, 1-hex), 2.07 (s, $\left.12 \mathrm{H}, \mathrm{C}_{6} \mathrm{H}_{2}\left(\mathrm{CH}_{3}\right)_{3}\right)$.

2.4. Crystal Structure Determination. Data Collection and Structure Solution and Refinement. Suitable crystals of 3-Mes, 3-SIMes, 3-IPr, and 4 were selected under a stereomicroscope while they were immersed in mineral oil to minimize contact with air or water. The crystal was removed from the oil using a tapered fiber, which also served to hold the crystal for data collection, and was mounted in a stream of cold nitrogen at 100(2) K. X-ray diffraction data were collected on a Bruker SMART APEX diffractometer with Mo K $\alpha(\lambda=0.71073 \AA)$ radiation. A Siemens Platform goniometer and a Charged Coupled Device (CCD) detector were used. The 
data were collected using a routine to survey the reciprocal space to the extent of a full sphere to a resolution of $0.75 \AA$ and were indexed by the APEX program. ${ }^{[56]}$ Rotation and still images showed diffractions to be sharp. Frames separated in reciprocal space were obtained and provided an orientation matrix and the initial cell parameters. Final cell parameters were obtained from the full data set. Integration of intensities and refinement of cell parameters were done using SAINT. The structures were solved by direct methods refined by iterative cycles of least-squares refinement on $\mathrm{F}^{2}$ followed by difference Fourier synthesis using the XS software. ${ }^{[57,58]}$ All nonhydrogen atoms were refined anisotropically. All hydrogen atoms were included in the final structure factor calculation at idealized positions and were allowed to ride on the neighboring atoms with relative isotropic displacement coefficients. Absorption corrections were based on a fitted function to the empirical transmission surface as sampled by multiple equivalent measurements. ${ }^{[59]}$ Observation during and after data collection showed that the crystal was still clear, suggesting no decomposition.

2.4.1. Crystal Structure of 3-IMes-2 $\left(\mathrm{C}_{7} \mathrm{H}_{8}\right)$. Red block crystals suitable for X-ray diffraction were obtained from a concentrated toluene solution left at $-35^{\circ} \mathrm{C}$ for 7 days. The systematic absences in the diffraction data were uniquely consistent for the space group $P 2_{1} / c$. Two molecules of toluene are present in the unit cell.

2.4.2. Crystal Structure of 3-SIMes. Red block crystals suitable for X-ray diffraction were obtained from a concentrated toluene solution layered with hexanes. The systematic absences in the diffraction data were uniquely consistent for the space group $P 2_{1}$. The structure was refined as an inversion twin, and the resulting Flack X parameter confirms we have the correct handedness.

2.4.3. Crystal Structure of 3-IPr$\cdot E t_{2} O$. Red block crystals suitable for X-ray diffraction were obtained from a concentrated diethyl ether solution at $-35^{\circ} \mathrm{C}$. The systematic absences in the diffraction data were uniquely consistent for the space group $P-1$. One diethyl ether molecule is present in the unit cell.

2.4.4. Crystal Structure of 4. Yellow needle crystals suitable for X-ray diffraction were obtained from a concentrated toluene solution layered with hexanes left at $-35^{\circ} \mathrm{C}$ for 7 days. The systematic absences in the diffraction data were uniquely consistent for the space group $P-1$. The unit cell contains 1.72 toluene molecules, which have been treated as a diffuse contribution to the overall scattering without specific atom positions by SQUEEZE/PLATON. ${ }^{[60]}$ 


\section{RESULTS AND DISCUSSION.}

3.1. Reaction of $\mathrm{Ni}(\mathrm{NHC})_{2}$ with Diphenyldiazomethane. A series of biscarbene $\mathrm{Ni}(0)$ complexes were synthesized using the carbenes IMes, SIMes and IPr (IMes = 1,3-bis(2,4,6trimethylphenyl)imidazol-2-ylidene, SIMes = 1,3-bis(2,4,6-trimethylphenyl)imidazolin-2ylidene and $\operatorname{IPr}=1,3$-bis(2,6-diisopropylphenyl)imidazol-2-ylidene) (Scheme 1). ${ }^{[61]}$ The reactions of these homoleptic complexes with diazoalkanes were investigated to study the possibility of performing group transfer chemistry.

Scheme 1. NHC ligands utilized in this work.

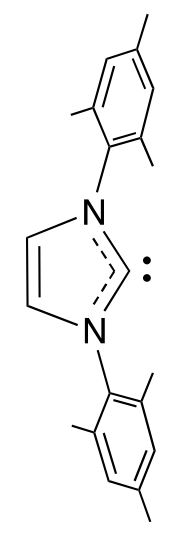

IMes

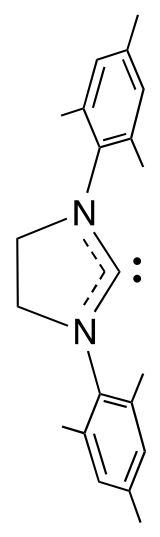

SIMes

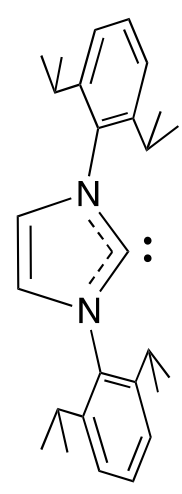

IPr

$\mathrm{Ni}(\mathrm{IMes})_{2}$ (1-IMes) was first prepared in 1994 by Arduengo, who took advantage of the bulky nature of IMes to prepare one of the first known two-coordinate homoleptic transition metal complexes (Scheme 2). ${ }^{[55]}$ This thermally stable, 14-electron Ni(0) complex is prepared as dark purple crystals by reaction of $\mathrm{Ni}(\operatorname{cod})_{2}$ ( $\operatorname{cod}=1,5$-cyclooctadiene) with 2 equivalents of the IMes ligand in tetrahydrofuran (THF). We found that this route also provides the analogous new complex Ni(SIMes) 2 (1-SIMes) in 92\% yield (Scheme 2). 
Scheme 2. Synthetic formation of 1-IMes and 1-SIMes.

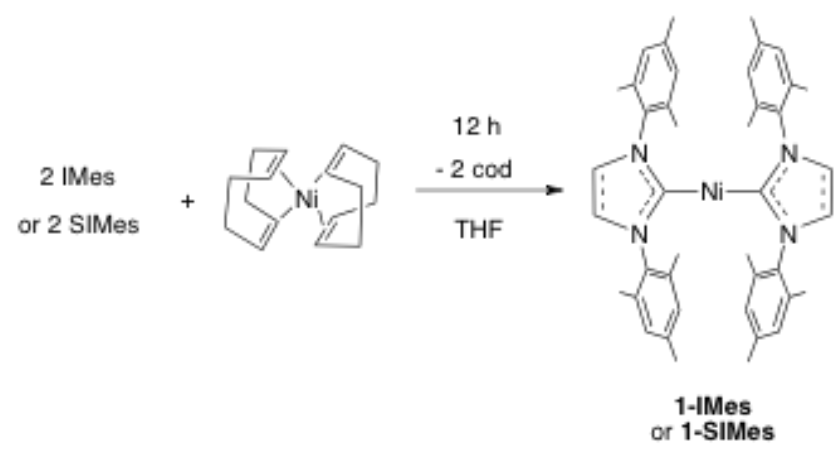

In contrast, reaction of $\mathrm{Ni}(\mathrm{cod})_{2}$ and 2 equivalents of IPr ligand forms an equilibrium between $\mathrm{Ni}(\mathrm{cod})_{2}$ and $\mathrm{Ni}(\operatorname{IPr})_{2}(\mathbf{1}-\mathrm{IPr}) \cdot{ }^{[62]}$ Only a $30 \%$ yield of 1-IPr could be isolated from this mixture in our hands. We therefore developed a new route to generate 1-IPr in good yield (Scheme 3). The known complex (IPr) ${ }_{2} \mathrm{NiCl}_{2}$, 2, was prepared as a pale pink powder in $95 \%$ yield from IPr and $\left(\mathrm{PPh}_{3}\right)_{2} \mathrm{NiCl}_{2} \cdot{ }^{[63]}$ Further reaction of $\mathbf{2}$ with 2.1 equivalents of $\mathrm{KC}_{8}$ affords $\mathbf{1 -}$ IPr as a purple-black powder. This method provides 1-IPr in better yield than NaH reduction starting from $\mathrm{Ni}(\mathrm{acac})_{2}{ }^{[64]}$ (acac = acetylacetonate) and in comparable yield to reductive elimination of ethane from (IPr) ${ }_{2} \mathrm{NiMe}_{2}$ without the necessity of isolating the sensitive Ni-alkyl intermediate. ${ }^{[65]}$

Scheme 3. Synthetic formation of 1-IPr.

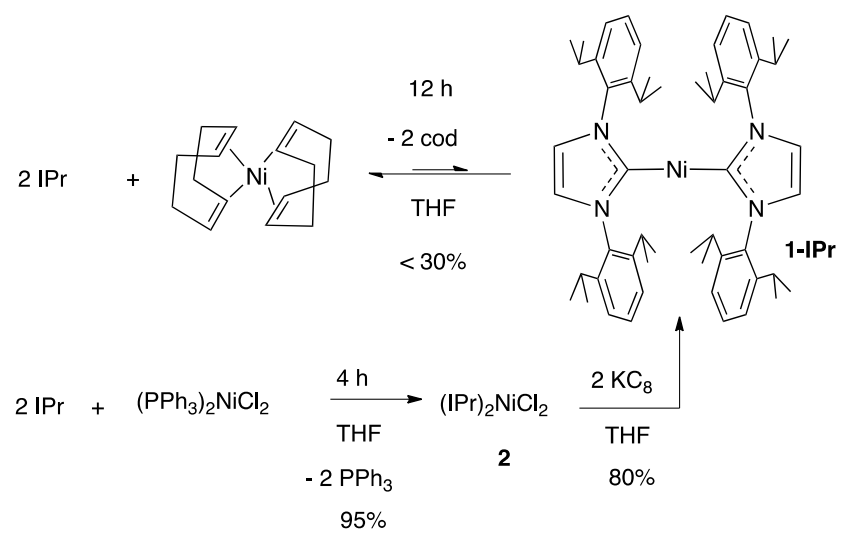


Treatment of $\mathrm{Ni}(\mathrm{NHC})_{2}$ (1-Mes, 1-SIMes, and 1-Pr) with 1 equivalent of diphenyldiazomethane at $-35{ }^{\circ} \mathrm{C}$ followed by stirring at room temperature for 1 hour in diethyl ether affords $(\mathrm{NHC})_{2} \mathrm{Ni}\left(\kappa^{1}-\mathrm{N}_{2} \mathrm{CPh}_{2}\right)$ (3-IMes, 3-SIMes, and 3-IPr). Removal of the ether under vacuum followed by washing with cold hexanes affords 3-IMes, 3-SIMes, and 3-IPr as red or orange-red solids in high yields (Scheme 4).

3.2. Structural Analysis of $(\mathrm{NHC})_{2} \mathrm{Ni}\left(\kappa^{1}-\mathrm{N}_{2} C P h_{2}\right)$ Complexes. The X-ray structures of complexes 3-IMes, 3-SIMes, and 3-IPr were investigated to determine how the diazoalkane ligand interacts with the Ni center. Crystals suitable for X-ray analysis of 3-IMes (Figure 1) were obtained from a concentrated toluene solution cooled to $-35^{\circ} \mathrm{C}$ while crystals of 3-SIMes (Figure 2) were obtained from a concentrated toluene solution layered with hexanes at room temperature. Crystals of 3-IPr (Figure 3) were obtained from a concentrated diethyl ether solution at -35 ${ }^{\circ} \mathrm{C}$.

Scheme 4. Synthetic formation of 3-IMes, 3-SIMes, and 3-IPr from their respective $\mathrm{Ni}(\mathrm{NHC})_{2}$ precursors.
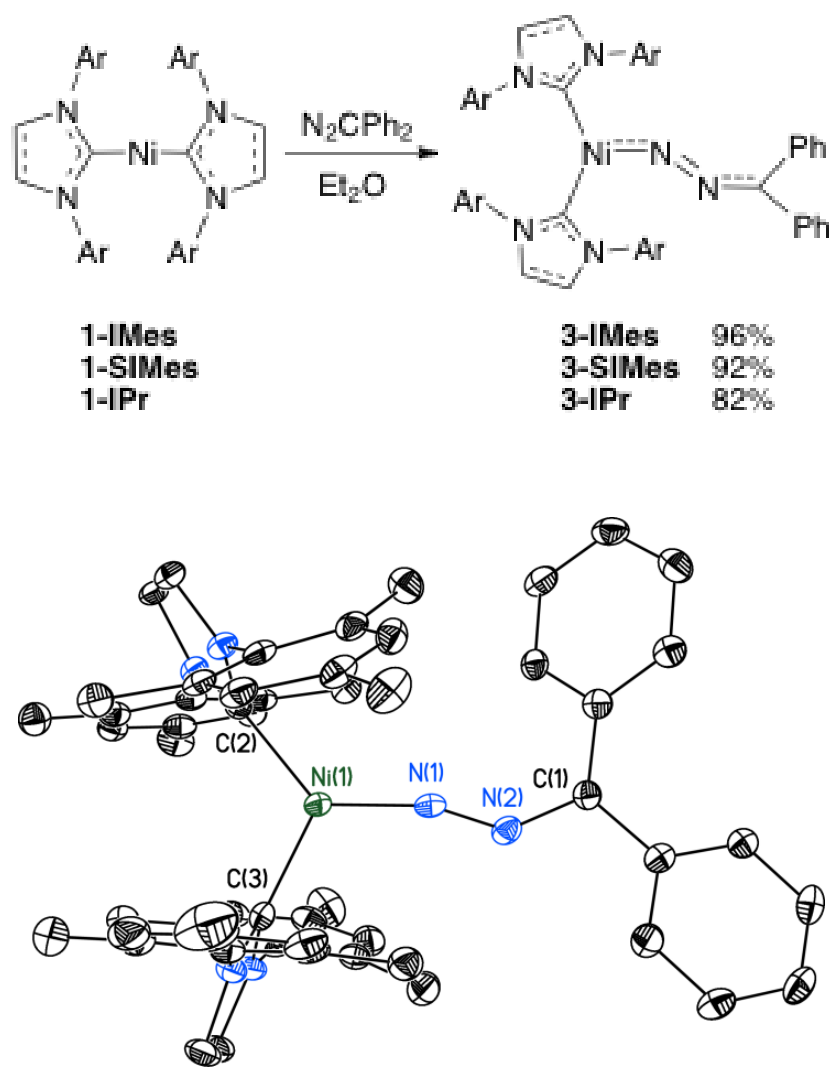

Figure 1. Thermal ellipsoid plot of (IMes) $)_{2} \mathrm{Ni}\left(\kappa^{1}-\mathrm{N}_{2} \mathrm{CPh}_{2}\right) \cdot 2\left(\mathrm{C}_{7} \mathrm{H}_{8}\right)\left(3-\mathrm{IMes} \cdot 2\left(\mathrm{C}_{7} \mathrm{H}_{8}\right)\right)$ drawn at $50 \%$ probability. $\mathrm{H}$ atoms and molecules of solvation omitted for clarity. 


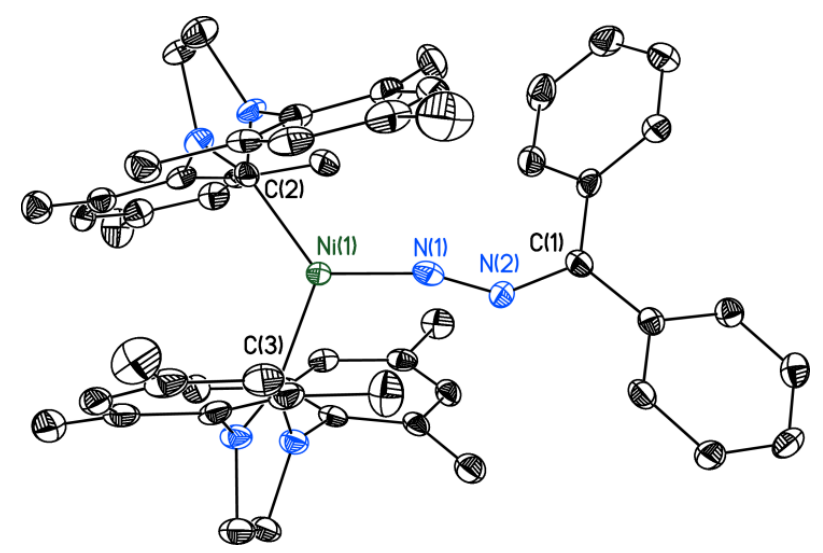

Figure 2. Thermal ellipsoid plot of (SIMes) ${ }_{2} \mathrm{Ni}\left(\kappa^{1}-\mathrm{N}_{2} \mathrm{CPh}_{2}\right)$ (3-SIMes) drawn at $50 \%$ probability. $\mathrm{H}$ atoms omitted for clarity.

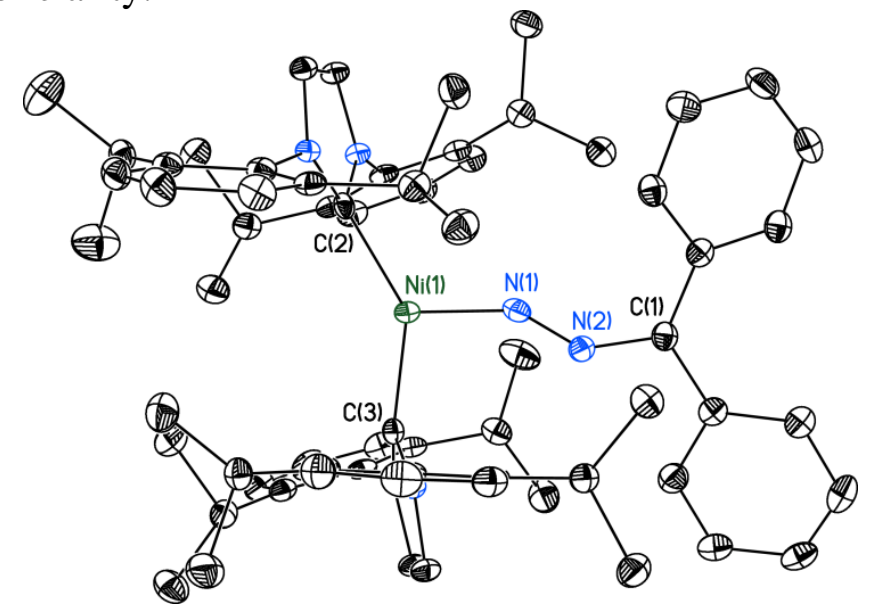

Figure 3. Thermal ellipsoid plot of $(\mathrm{IPr})_{2} \mathrm{Ni}\left(\kappa^{1}-\mathrm{N}_{2} \mathrm{CPh}_{2}\right) \cdot \mathrm{Et}_{2} \mathrm{O}\left(3-\mathrm{IPr} \cdot \mathrm{Et}_{2} \mathrm{O}\right)$ drawn at 50\% probability. $\mathrm{H}$ atoms and molecules of solvation omitted for clarity.

Table 1. Selected bond lengths $(\AA)$ and angles $\left(^{\circ}\right)$ for 3.

\begin{tabular}{llll}
\hline & 3-IMes & 3-SIMes & 3-IPr \\
\hline $\mathrm{Ni}-\mathrm{N}(1)(\AA)$ & $1.721(2)$ & $1.728(4)$ & $1.748(2)$ \\
$\mathrm{N}(1)-\mathrm{N}(2)(\AA)$ & $1.231(3)$ & $1.208(5)$ & $1.219(2)$ \\
$\mathrm{N}(2)-\mathrm{C}(1)(\AA)$ & $1.349(4)$ & $1.338(5)$ & $1.339(3)$ \\
$\mathrm{Ni}-\mathrm{C}(2)(\AA)$ & $1.942(3)$ & $1.921(4)$ & $1.984(2)$ \\
$\mathrm{Ni}-\mathrm{C}(3)(\AA)$ & $1.907(3)$ & $1.910(4)$ & $1.914(2)$ \\
$\mathrm{Ni}-\mathrm{N}(1)-\mathrm{N}(2)\left(^{\circ}\right)$ & $161.5(2)$ & $159.1(3)$ & $147.2(2)$ \\
$\mathrm{N}(1)-\mathrm{N}(2)-\mathrm{C}(1)\left(^{\circ}\right)$ & $137.7(3)$ & $139.1(4)$ & $139.8(2)$ \\
$\mathrm{C}(2)-\mathrm{Ni}-\mathrm{C}(3)\left(^{\circ}\right)$ & $114.7(1)$ & $123.8(2)$ & $142.80(9)$ \\
\hline
\end{tabular}


The crystal structures of all three complexes reveal planar, three-coordinate Ni centers in which the $\mathrm{N}_{2} \mathrm{CPh}_{2}$ ligand is coordinated in an end-on $\kappa^{1}$ fashion to the metal. The angle between the NHC ligands [C(2)-Ni-C(3): 3-IMes 114.7(1) ${ }^{\circ}<$ 3-SIMes 123.8(2) $<3$-IPr 142.80(9) ${ }^{\circ}$ lie in the order consistent with the relative bulk of the three ligands as measured by percent buried volume. ${ }^{[66,67]}$ The Ni-N(1) bond lengths of the complexes $(1.721-1.7482 \AA)$ fall between the experimentally obtained value for a $\mathrm{Ni}-\mathrm{N}$ single bond distance of $1.881(2) \AA$ and the $\mathrm{Ni}=\mathrm{N}$ double bond distance of 1.702(2) $\AA$ as observed in (dtbpe)Ni-NH(2,6- ${ }^{\mathrm{i}} \mathrm{PrC}_{6} \mathrm{H}_{3}$ ) and (dtbpe) $\mathrm{Ni}=\mathrm{N}\left(2,6-{ }^{\mathrm{i}} \mathrm{PrC}_{6} \mathrm{H}_{3}\right)$ (dtbpe $=1$,2-bis(di-tert-butylphosphino)ethane), respectively. ${ }^{[68]}$ The $\mathrm{N}(1)-\mathrm{N}(2)$ bond lengths for the complexes $(1.208-1.231 \AA)$ are closer to typical $\mathrm{N}=\mathrm{N}$ double bonds $\left(\sim 1.24 \AA\right.$ ) than typical N-N single bonds $(\sim 1.45 \AA) .{ }^{[69]}$ The N(2)-C(1) bond lengths for the complexes $(1.338-1.349 \AA)$ are comparable to typical partial double bonds found in pyridine (1.352 $\AA)$. ${ }^{[70]}$ This lengthening (and weakening) of what would be expected for a $\mathrm{C}=\mathrm{N}$ double bond, is consistent with the observed reduction in $v(\mathrm{C}=\mathrm{N})$ upon diazoalkane binding to a metal center, from $2032 \mathrm{~cm}^{-1}$ for free $\mathrm{N}_{2} \mathrm{CPh}_{2}{ }^{[71]}$ to $1560 \mathrm{~cm}^{-1}$ observed for each of these three complexes. The Ni-N(1)-N(2) $\left(147.2-161.5^{\circ}\right)$ and $\mathrm{N}(1)-\mathrm{N}(2)-\mathrm{C}(1)\left(137.7-139.8^{\circ}\right)$ bond angles show significant deviations from linearity. Collectively, the metrical data for 3-IMes, 3SIMes, and 3-IPr are consistent with a bonding mode that is intermediate between $\mathbf{A}_{\mathbf{2}}$ and $\mathbf{A}_{\mathbf{3}}$.

The $\kappa^{1}$ coordination of $\mathrm{N}_{2} \mathrm{CPh}_{2}$ observed for 3-IMes, 3-SIMes and 3-IPr contrasts with that observed for $\mathrm{L}_{2} \mathrm{Ni}\left(\mathrm{N}_{2} \mathrm{CR}_{2}\right)$ complexes with smaller $\mathrm{L}$ ligands. Radius reported that when $\mathrm{L}$ is ${ }^{\mathrm{i}} \mathrm{Pr}_{2} \operatorname{Im}\left({ }^{\mathrm{i}} \mathrm{Pr}_{2} \mathrm{Im}=1\right.$,3-diisopropylimidazol-2-ylidene), then $\mathrm{N}_{2} \mathrm{CPh}_{2}$ forms an $\eta^{2}-\mathrm{N}, \mathrm{N}$ complex of type $\mathbf{B}$ (Figure 1). ${ }^{[27]}$ The smaller size of ${ }^{\mathrm{i}} \mathrm{Pr}_{2} \mathrm{Im}$ allows the $\mathrm{C}-\mathrm{Ni}-\mathrm{C}$ angle to contract to $104.8(2)^{\circ}$ (cf. $114.7-142.8^{\circ}$ for 3 ), which affords room for the side-on binding of the diazoalkane. Otsuka and Ibers have also crystallographically characterized a similar complex where $\mathrm{Ni}\left(\mathrm{CN}^{\mathrm{t}} \mathrm{Bu}\right)_{2}$ binds diazafluorene in a type-B $\eta^{2}-\mathrm{N}, \mathrm{N}$ fashion. ${ }^{[23]}$ Here again the $\mathrm{C}-\mathrm{Ni}-\mathrm{C}$ angle of $100.4(2)^{\circ}$ is significantly smaller than those seen in $\mathbf{3}$.

3.3. Reaction and structural analysis of $\mathrm{Ni}(\mathrm{IMes})_{2}$ with 1-Azidoadamantane. The observation that the (NHC) $)_{2} \mathrm{Ni}\left(\kappa^{1}-\mathrm{N}_{2} \mathrm{CPh}_{2}\right)$ complexes 3-IMes, 3-SIMes, and 3-IPr are resistant to elimination of $\mathrm{N}_{2}$ and thus do not form carbene complexes (vide infra) suggested that analogous azide species could exhibit similar properties. 1-Azidoadamantane $\left(\mathrm{N}_{3} \mathrm{Ad}\right)$ was chosen because it is capable of many of the same binding modes as diphenyldiazomethane yet possesses steric bulk further from the terminal $\mathrm{N}=\mathrm{N}$ moiety. 
The reaction of $\mathrm{N}_{3} \mathrm{Ad}$ with 1-IMes in tetrahydrofuran yields a yellow solution (Scheme 5). No gas evolution was observed. From this solution, after concentration and layering with hexanes, crystals of $\mathbf{4}$ were isolated. An X-ray diffraction study of $\mathbf{4}$ revealed an $\eta^{2}$-azide adduct coordinated through the terminal $\mathrm{N}$ atoms (Figure 4). The $\mathrm{C}-\mathrm{Ni}-\mathrm{C}$ angle in 4 of $120.1(1)^{\circ}$ is even larger than that seen in 3-IMes $\left(114.7(1)^{\circ}\right)$. The ${ }^{1} \mathrm{H}$ NMR spectrum reveals a diamagnetic compound that is fluxional in solution.

Scheme 5. Synthetic formation of 4 from 1-IMes.
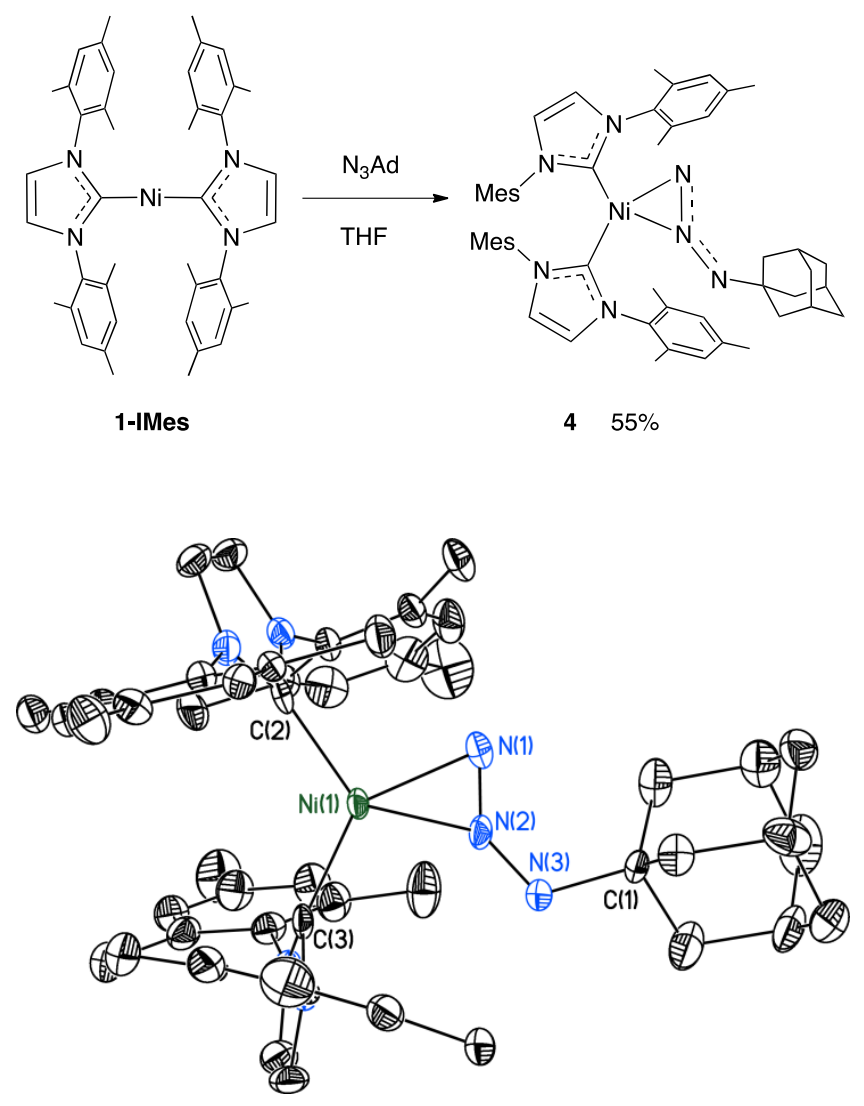

Figure 4. Thermal ellipsoid plot of (IMes) ${ }_{2} \mathrm{Ni}\left(\eta^{2}-\mathrm{N}_{3} \mathrm{Ad}\right)$ (4) drawn at $50 \%$ probability. H-atoms omitted for clarity. Select bond lengths $(\AA)$ and angles $\left({ }^{\circ}\right)$ : Ni(1)-N(1) $=1.926(3), \mathrm{Ni}(1)-\mathrm{N}(2)=$ 1.826(3), $\mathrm{N}(1)-\mathrm{N}(2)=1.234(4), \mathrm{N}(2)-\mathrm{N}(3)=1.311(4), \mathrm{N}(3)-\mathrm{C}(1)=1.487(5), \mathrm{Ni}(1)-\mathrm{C}(2)=$ 1.914(4), Ni(1)-C(3) = 1.918(4), C(2)-Ni(1)-C(3) = 120.1(1), N(1)-Ni(1)-N(2) = 38.3(1), N(1)$\mathrm{N}(2)-\mathrm{N}(3)=139.9(3), \mathrm{N}(2)-\mathrm{N}(3)-\mathrm{C}(1)=114.6(3)$.

3.4. Reactivity of (NHC) $)_{2} \mathrm{Ni}\left(\kappa^{1}-\mathrm{N}_{2} \mathrm{CPh}_{2}\right)$ Complexes. The utility of 3-IMes, 3-SIMes and 3-IPr as precursors for Ni-carbene complexes was explored by studying their thermal and photochemical stability. Complexes 3-IMes, 3-SIMes, and 3-IPr are remarkably robust under an inert 
atmosphere in benzene up to $60{ }^{\circ} \mathrm{C}$ and do not undergo $\mathrm{N}_{2}$ loss under thermal or photochemical conditions. At $60{ }^{\circ} \mathrm{C}$, however, the diazoalkane ligand dissociates from the metal center to regenerate 1 cleanly.

Computational studies suggest that the formation of a carbene complex from a diazoalkane must involve the intermediacy of a $\kappa^{2}-\mathrm{C}, \mathrm{N}$ metallacycle (type $\mathbf{D}$, Chart 1 ) or $\kappa^{1}$-C diazoalkane intermediate (type $\mathbf{E}$, Chart 1 ). ${ }^{[72]}$ Such a binding motif is unlikely in these complexes because of steric constraints imposed by the bulky NHC ligands. Space-filling models of 3-IMes and 3-IPr (Figure 5), where $\mathrm{N}_{2} \mathrm{CPh}_{2}$ is coordinated to the Ni center in the $\kappa^{1}-\mathrm{N}$ binding mode, show considerable steric interaction between the phenyl substituents of $\mathrm{N}_{2} \mathrm{CPh}_{2}$ and the aryl substituents of the NHC ligand . This interaction would only be further exacerbated in $\kappa^{1}-\mathrm{C}$ or $\kappa^{2}-$ C,N binding modes.
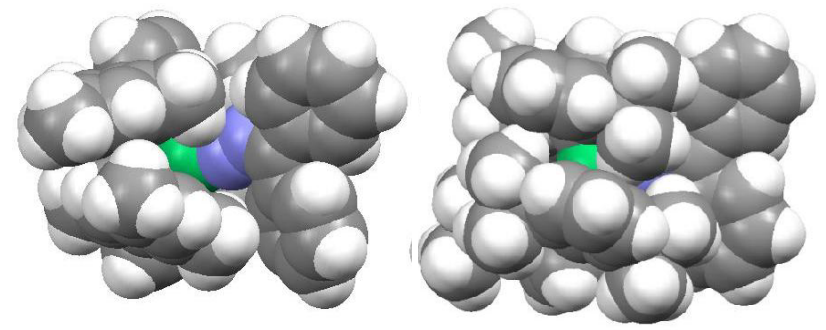

Figure 5. Space-filling models of (IMes) ${ }_{2} \mathrm{Ni}\left(\kappa^{1}-\mathrm{N}_{2} \mathrm{CPh}_{2}\right)$ (3-IMes, left) and $(\mathrm{IPr})_{2} \mathrm{Ni}\left(\kappa^{1}-\mathrm{N}_{2} \mathrm{CPh}_{2}\right)$ (3-IPr, right).

While the (NHC) ${ }_{2} \mathrm{Ni}\left(\kappa^{1}-\mathrm{N}_{2} \mathrm{CPh}_{2}\right)$ complexes 3 do not eliminate $\mathrm{N}_{2}$ to form stable carbenes, they do undergo stoichiometric and catalytic group transfer with alkenes to give cyclopropane products (Table 2). Treatment of a toluene solution of 3-IMes with 1-hexene (1 equiv, 60 ${ }^{\circ} \mathrm{C}, 2 \mathrm{~h}$ ) affords 1-IMes and 1,1-diphenyl-2-butylcyclopropane in 90\% yield, while reaction with 1-methyl-2-butene, 2-hexene, or cyclohexene provides the corresponding cyclopropane products in good yield.

Table 2. Stoichiometric group transfer reactions of (IMes) ${ }_{2} \mathrm{Ni}\left(\kappa^{1}-\mathrm{N}_{2} \mathrm{CPh}_{2}\right)$ (3-IMes). 


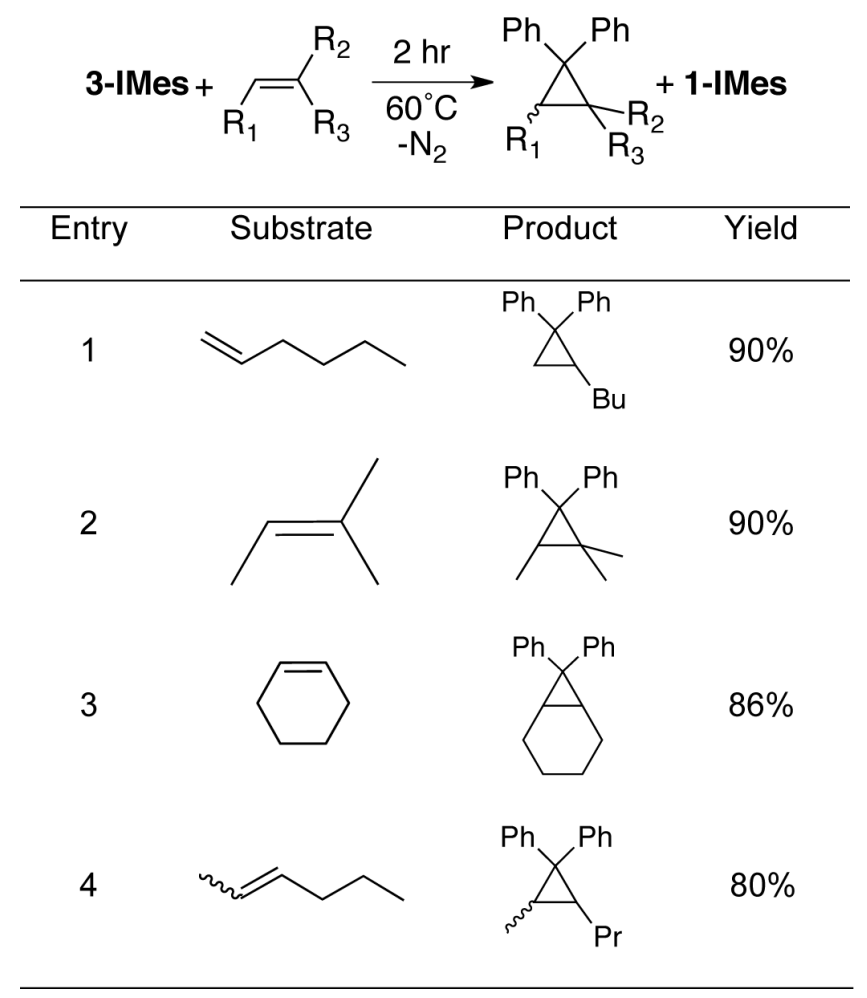

The ability of $\mathrm{Ni}(\mathrm{NHC})_{2}$ to catalyze cyclopropanation was also tested (Scheme 6). Toluene solutions of 1-hexene react with $\mathrm{N}_{2} \mathrm{CPh}_{2}$ (1 equiv, $60{ }^{\circ} \mathrm{C}, 12 \mathrm{~h}$ ) with 20 mol\% 3-IMes or 1IMes to give the corresponding cyclopropane in 90\% isolated yield. There is no distinguishable difference between the catalytic rates of 3-IMes and 1-IMes, which is not surprising as 3-IMes readily converts to 1 -IMes at $60{ }^{\circ} \mathrm{C}$. The high reactivity of metal-stabilized carbenoids usually requires cyclopropanation reactions to be performed with excess olefin, by slow addition of diazoalkane, or both, to minimize the concentration of carbenes and thus avoid dimerization side products. ${ }^{[9,73-76]}$ The ability of 1-IMes to give high yields of cyclopropanation with a 1:1 ratio of diazoalkane to olefin is therefore particularly noteworthy.

Scheme 6. Synthetic formation of 1,1-diphenyl-2-butylcyclopropane mediated by catalytic amounts of either 1-IMes or 3-IMes.

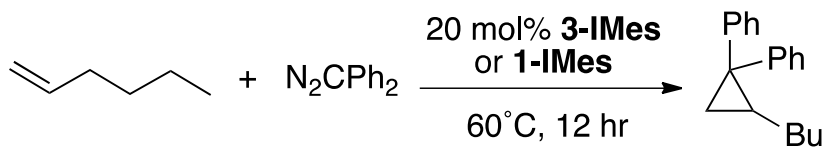


3.5. Proposed catalytic cycle for cyclopropanation. Most transition-metal mediated cyclopropanation reactions are proposed to proceed through a metallacarbene intermediate, ${ }^{[77-80]}$ but this is not always the case. Peace has proposed diazoalkane attack on a Cu-coordinated olefin as one of the pathways by which cyclopropanes are formed with $\left[(\mathrm{MeO})_{3} \mathrm{P}\right]_{2} \mathrm{CuI}$ or $\mathrm{Cu}(\mathrm{acac})_{2},{ }^{[81]}$ and Maulide has proposed olefin activation for a series of Au-catalyzed intramolecular cyclopropanations where the putative metallacarbene complex is inactive for cyclopropanation. ${ }^{[82]}$ A metallocarbene intermediate is unlikely with 3-IMes because, at the elevated temperature required for cyclopropanation, the diazoalkane ligand dissociates from the metal center rather than form a carbene (vide supra). Therefore, another catalytic pathway is probably operative.

The ability of olefins to coordinate to a metal center has significant effects on the rate and selectivity for cyclopropanations with such catalysts as CuOTf and $\mathrm{Pd}(\mathrm{OAc})_{2}{ }^{[83]}$ When excess 1hexene is added to $\mathrm{C}_{6} \mathrm{D}_{6}$ solutions of 1-IMes, a color change occurs from purple to red and complete conversion to a new complex is observed. The ${ }^{1} \mathrm{H}$ NMR spectrum of this complex is consistent with an $\eta^{2}$-coordination of 1-hexene to the metal with one alkene molecule for every two IMes ligands, (IMes) ${ }_{2} \mathrm{Ni}\left(\eta^{2}-\mathrm{C}_{6} \mathrm{H}_{12}\right)$ (5) (Scheme 7). A similar mono-alkene adduct was characterized by Radius who isolated $\left({ }^{\mathrm{i}} \mathrm{Pr}_{2} \mathrm{Im}\right)_{2} \mathrm{Ni}\left(\mathrm{C}_{2} \mathrm{H}_{4}\right)$ from reaction of $\left({ }^{\mathrm{i}} \mathrm{Pr}_{2} \mathrm{Im}_{4}{ }_{4} \mathrm{Ni}_{2}\right.$ (cod) and ethylene. ${ }^{[84]}$ Solutions of 5 in $\mathrm{C}_{6} \mathrm{D}_{6}$ are stable up to $80{ }^{\circ} \mathrm{C}$ with no sign of degradation by ${ }^{1} \mathrm{H}$ NMR. Upon removal of the solvent under vacuum, 5 completely reverts to 1-IMes. In contrast, $\left({ }^{\mathrm{i}} \mathrm{Pr}_{2} \mathrm{Im}\right)_{2} \mathrm{Ni}\left(\mathrm{C}_{2} \mathrm{H}_{4}\right)$, with smaller NHC ligands, is stable under vacuum. ${ }^{[84]}$

Scheme 7. Synthetic formation of 5 upon coordination of 1-hexene to 1-IMes.

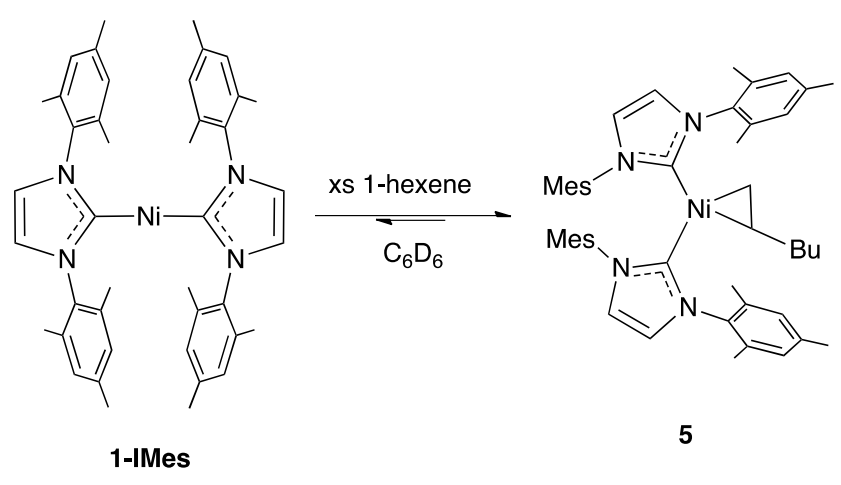

Under cyclopropanation reaction conditions at $60{ }^{\circ} \mathrm{C}$, it is clear that the diazoalkane adduct is not stable but that the olefin adduct is. Thus, we propose a catalytic cycle where 1-IMes 
(I) activates the olefin (II) for electrophilic attack by the diazoalkane (Scheme 8) in a similar manner to that observed by Peace. ${ }^{[81]} \mathrm{N}_{2}$ elimination from the intermediate complex (III) would likely proceed with little to no barrier, and dissociation of the cyclopropane or displacement by olefin should be facile to turn over the catalytic cycle.

Scheme 8. Proposed catalytic cycle for formation of cyclopropanation products.

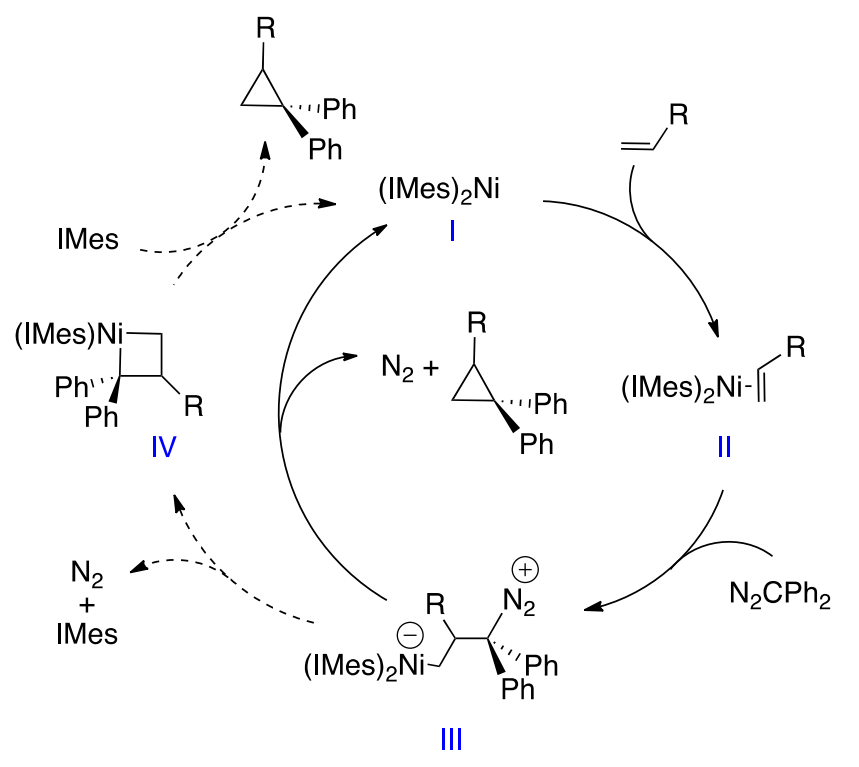

Alternatively, III could eliminate $\mathrm{N}_{2}$ to form a modified metallacyclobutane (IV). ${ }^{\left[{ }^{[5]}\right.}$ It seems unlikely a metallacyclobutane intermediate supported by two IMes ligands would be sterically achievable (vide supra), but it is possible to envision one IMes ligand dissociating before formation of the metallacyclobutane. After reductive elimination of the cyclopropane product and re-association of IMes, the starting complex (I) could be regenerated to complete the catalytic cycle. An argument against this mechanism is that IMes is known to react with $\mathrm{N}_{2} \mathrm{CPh}_{2},{ }^{[86]}$ for Clyburne has shown that these reagents form the corresponding azine in $48 \%$ yield after stirring at room temperature overnight. While we did not perform this control ourselves, our elevated reaction conditions $\left(60^{\circ} \mathrm{C}\right.$ for $12 \mathrm{~h}$ ) would likely increase the relative azine yield. Such a reaction would decrease the amount of $\mathrm{N}_{2} \mathrm{CPh}_{2}$ available to react with our olefin, which should therefore give a poor overall yield for the cyclopropane product. Due to the high overall yield seen here for these cyclopropane products, this alternative mechanism is inconsistent with experimental results. 
3.6. Reactivity of (IMes) $)_{2} \mathrm{Ni}\left(\eta^{2}-N_{3} A d\right)$ (4). Several related Ni complexes with $\eta^{2}$-bound azide ligands are known. ${ }^{[87,88]} \mathrm{N}_{3} \mathrm{Ad}$ and $\mathrm{N}_{3} \mathrm{Mes}$ (Mes = 2,4,6-trimethylphenyl) both bind to $\mathrm{Ni}$ in an $\eta^{2}$ fashion when Ni is supported by the chelating dtbpe ligand. ${ }^{[87]}$ This also occurs when Ni is supported by the chelating NHC ligand TMTBM (TMTBM = 3,3'-methylenebis(1-tert-butyl4,5-dimethylimidazol-iylidene)) and reacts with $\mathrm{N}_{3}\left(2,6-{ }^{\mathrm{i}} \mathrm{Pr}_{2} \mathrm{C}_{6} \mathrm{H}_{3}\right)$ and $\mathrm{N}_{3} \mathrm{dmp}$ (dmp $=$ 2,6dimesitylphenyl) to form (TMTBM)Ni $\left\{\eta^{2}-\mathrm{N}_{3}\left(2,6-{ }^{\mathrm{i}} \mathrm{Pr}_{2} \mathrm{C}_{6} \mathrm{H}_{3}\right)\right\}$ and (TMTBM)Ni( $\left.\eta^{2}-\mathrm{N}_{3} \mathrm{dmp}\right)$, respectively. ${ }^{[88]}$ While $\mathbf{4}$ is structurally similar to these reported $\eta^{2}$-azides, its reactivity is distinct. 4 is stable up to $60{ }^{\circ} \mathrm{C}$, at which point dissociation of azide occurs to regenerate 1-IMes; formation of the corresponding imido complex is not observed. Cooling the mixture of 1-IMes and $\mathrm{N}_{3} \mathrm{Ad}$ to room temperature results in the reformation of $\mathbf{4}$ along with significant decomposition. In contrast, heating (dtbpe) $\mathrm{Ni}\left(\eta^{2}-\mathrm{N}_{3} \mathrm{Ad}\right)$ or (dtbpe) $\mathrm{Ni}\left(\eta^{2}-\mathrm{N}_{3} \mathrm{Mes}\right)$ to $50{ }^{\circ} \mathrm{C}$ results in loss of $\mathrm{N}_{2}$ and formation of three-coordinate imido complexes. ${ }^{[87]}$ In the case of (TMTBM)Ni $\left\{\eta^{2}-\mathrm{N}_{3}(2,6-\right.$ $\left.{ }^{\mathrm{i}} \mathrm{Pr}_{2} \mathrm{C}_{6} \mathrm{H}_{3}\right)$ \}, $\mathrm{N}_{2}$ extrusion could not be induced thermally, chemically, or photochemically. ${ }^{[88]}$ However, use of a bulkier azide complex (TMTBM)Ni $\left(\eta^{2}-\mathrm{N}_{3} \mathrm{dmb}\right)$ yielded an imido complex. This result does not appear to be general, however, as we found that reaction of 1-IMes with $\mathrm{N}_{3} \mathrm{dmp}$ resulted in decomposition without any apparent formation of an imido complex. ${ }^{[88]}$ Thus, only for $\mathbf{4}$ is even partially reversible azide coordination observed.

A more direct comparison between $\mathbf{4}$ and (dtbpe) $\mathrm{Ni}\left(\eta^{2}-\mathrm{N}_{3} \mathrm{Ad}\right)$ is warranted because the two complexes have a similar coordination mode of the identical organoazide to a $\mathrm{Ni}(0)$ center but exhibit very different reactivity (vide supra). This difference is most likely due to the steric and chelating effects of the NHC versus dtbpe ligands. Pörschke’s complex ( $\{(\mathrm{dtbpe}) \mathrm{Ni}\}_{2}\left(\eta^{2}-\mu-\right.$ $\left.\mathrm{C}_{6} \mathrm{H}_{6}\right)$ ) was used to synthesize (dtbpe) $\mathrm{Ni}\left(\eta^{2}-\mathrm{N}_{3} \mathrm{Ad}\right.$ ), and during coordination of $\mathrm{N}_{3} \mathrm{Ad}$ to the $\mathrm{Ni}$ center the P-Ni-P bite angle hardly changes (from 93.88(1) ${ }^{\circ}$ to $\left.93.75(2)^{\circ}\right) .{ }^{[87,89]}$ Upon loss of $\mathrm{N}_{2}$ to form the corresponding imido complex (dtbpe)Ni=NAd, this bite angle contracts slightly to 91.69(3) ${ }^{\circ}$. This reactivity is due to the stability imparted by the chelating dtbpe ligand: the coordinating $\mathrm{N}_{3} \mathrm{Ad}$ ligand is not sterically encumbered and so has the necessary space to form the proposed $\kappa^{2}-\mathrm{N}, \mathrm{N}$ metallacyclic intermediate required to induce loss of $\mathrm{N}_{2}{ }^{[87]}$ Thus, the geometry of the $\mathrm{Ni}$ center in the dtbpe system is independent of the identity of the coordinated azide ligand. In our current system, the $\mathrm{C}-\mathrm{Ni}-\mathrm{C}$ bite angle changes from $180^{\circ}$ in 1-IMes to $120.1(1)^{\circ}$ upon coordination of $\mathrm{N}_{3} \mathrm{Ad}$ to form $\mathbf{4}$. If $\mathbf{4}$ were to form an imido complex, this would probably occur via a metallacyclic intermediate analogous to that proposed for formation of (dtbpe)Ni=NAd 
from (dtbpe)Ni( $\left.\eta^{2}-\mathrm{N}_{3} \mathrm{Ad}\right){ }^{\left[{ }^{[87]}\right.}$ This transformation would require further contraction of the $\mathrm{C}-\mathrm{Ni}-$ C bite angle, which is unfavorable, and place the large Ad group in proximity to the mesityl groups of the NHC. This is not a problem with (dtbpe)Ni( $\eta^{2}-\mathrm{N}_{3} \mathrm{Ad}$ ) because the ${ }^{\mathrm{t}} \mathrm{Bu}$ groups are pulled back from the Ni center by the chelating phosphine. Therefore, at the elevated temperatures required to induce $\mathrm{N}_{2}$ loss and transform (dtbpe) $\mathrm{Ni}\left(\eta^{2}-\mathrm{N}_{3} \mathrm{Ad}\right.$ ) to (dtbpe)Ni=NAd, it is more favorable for $\mathrm{N}_{3} \mathrm{Ad}$ to dissociate from 4 to generate the stable, linear 1-IMes precursor, before reforming 4 upon cooling.

Complex 4 was also examined for stoichiometric alkane aziridination with 1-hexene in the same manner that 3-IMes was studied (vide supra) so as to allow for direct comparison between these systems. Upon exposure of 4 to 1-hexene and heating to $60^{\circ} \mathrm{C}$, the corresponding aziridination product was not generated. This lack of reactivity is likely due to dissociation and partial decomposition of the $\mathrm{N}_{3} \mathrm{Ad}$ unit from the $\mathrm{Ni}$ center at $60{ }^{\circ} \mathrm{C}$ without loss of $\mathrm{N}_{2}$ or formation of the coordinated imido for reasons described previously. Additionally, since 1-hexene coordinates to the Ni center in 1-IMes to form $\mathbf{5}$, which is stable up to $80^{\circ} \mathrm{C}$, it is likely that, at $60{ }^{\circ} \mathrm{C}$, the alkene displaces $\mathrm{N}_{3} \mathrm{Ad}$ without reacting. Thus, while 1-IMes has the capacity to bind both diazoalkanes and organoazides to form coordinated $\mathrm{Ni}(0)$ species, only the bound diazoalkane adducts are useful for group transfer reactivity under the conditions tested here.

\section{Conclusions.}

In conclusion, we have prepared and characterized the complexes (IMes) ${ }_{2} \mathrm{Ni}\left(\kappa^{1}-\mathrm{N}_{2} \mathrm{CPh}_{2}\right.$ ) (3-IMes), (SIMes) ${ }_{2} \mathrm{Ni}\left(\kappa^{1}-\mathrm{N}_{2} \mathrm{CPh}_{2}\right)$ (3-SIMes), and (IPr) ${ }_{2} \mathrm{Ni}\left(\kappa^{1}-\mathrm{N}_{2} \mathrm{CPh}_{2}\right)$ (3-IPr), all of which possess a $\kappa^{1}-\mathrm{N}$ end-on coordination mode to the $\mathrm{Ni}$ center through the terminal nitrogen atom of the diazoalkane ligand. All three complexes display $\mathrm{Ni}-\mathrm{N}-\mathrm{N}$ and $\mathrm{N}-\mathrm{N}-\mathrm{C}$ angles that significantly depart from linearity and have extensive delocalization of the $\pi$-bonds in the diazoalkane. We have also prepared and characterized the organoazide complex (IMes) $)_{2} \mathrm{Ni}\left(\eta^{2}-\mathrm{N}_{3} \mathrm{Ad}\right.$ ) (4) which possesses an $\eta^{2}$ coordination of the azide ligand to the Ni center. While elimination of $\mathrm{N}_{2}$ from these complexes to create a new family of terminal Ni carbene and terminal imido complexes does not occur, 3-IMes was successfully utilized in stoichiometric and catalytic olefin cyclopropanation reactions by producing cyclopropane products in good yields from 1:1 mixtures of diazoalkanes and olefins. 3-IMes mediates cyclopropanation with remarkable efficiency, and so 
these complexes are a promising starting point for the development of a new class of cyclopropanation catalysts.

\section{ACKNOWLEDGEMENTS.}

This paper is dedicated to the memory of Prof. Gregory L. Hillhouse who was a terrific advisor and mentor. This work was supported by National Science Foundation through grants CHE0957816, CHE-1266281, CHE-0615274 (to G.L.H.). We thank Prof. Michael Hopkins and Prof. Richard Jordan for their comments on and assistance with the manuscript.

\section{APPENDIX A. SUPPLEMENTARY DATA.}

CIF files contain the supplementary crystallographic data for this paper. Crystallographic data tables, ${ }^{1} \mathrm{H} /{ }^{13} \mathrm{C}$ NMR, and mass spectra files for the structures of compounds 3-IMes, 3-SIMes, 3IPr, and 4, as well as alternative syntheses for 1-IMes, 1-IPr, and 2, can be found in the supplementary data for this article.

\section{CoRRESPONDING AUTHOR}

* E-mail: nharrold@uchicago.edu

\section{Present AdDRess}

¥ Department of Chemistry, University of Wisconsin-Madison, Madison, WI 53706, USA.

\section{NoTES}

The authors declare no competing financial interest.

$\perp$ Deceased March 6, 2014.

\section{REFERENCES.}

[1] D. Seyferth, Chem. Rev. 1955, 55, 1155-1177.

[2] W. R. Roper, J. Organomet. Chem. 1986, 300, 167-190.

[3] H. Werner, J. Organomet. Chem. 1995, 500, 331-336.

[4] W. A. Herrmann, Angew. Chem. Int. Ed. 1978, 17, 800-812.

[5] M. P. Doyle, Chem. Rev. 1986, 86, 919-939.

[6] D. A. Lemenovskii, M. Putala, Russ. Chem. Rev. 1994, 63, 197-216.

[7] Y. Mizobe, Y. Ishii, M. Hidai, Coord. Chem. Rev. 1995, 139, 281-311.

[8] A. Padwa, M. D. Weingarten, Chem. Rev. 1996, 96, 223-270.

[9] M. P. Doyle, D. C. Forbes, Chem. Rev. 1998, 98, 911-936.

[10] H. M. L. Davies, S. A. Panaro, Tetrahedron 2000, 56, 4871-4880. 
[11] H. M. L. Davies, E. G. Antoulinakis, J. Organomet. Chem. 2001, 617-618, 47-55.

[12] R. Beckhaus, C. Santamaría, J. Organomet. Chem. 2001, 617-618, 81-97.

[13] D. Sutton, Chem. Rev. 1993, 93, 995-1022.

[14] M. Dartiguenave, M. J. Menu, E. Deydier, D. Yves, H. Siebald, Coord. Chem. Rev. 1998, 178-180, 623-663.

[15] N. P. Mankad, J. C. Peters, Chem. Commun. 2008, 1061-1063.

[16] J. J. Curley, T. Murahashi, C. C. Cummins, Inorg. Chem. 2009, 48, 7181-7193.

[17] K. Kromm, F. Hampel, J. A. Gladysz, Organometallics 2002, 21, 4264-4274.

[18] O. L. Sydora, D. S. Kuiper, P. T. Wolczanski, E. B. Lobkovsky, A. Dinescu, T. R. Cundari, Inorg. Chem. 2006, 45, 2008-2021.

[19] M. E. García, D. García-Vivó, M. A. Ruiz, P. Herson, Organometallics 2008, 27, 38793891.

[20] U. J. Kilgore, C. A. Sengelaub, M. Pink, A. R. Fout, D. J. Mindiola, Angew. Chem. Int. Ed. 2008, 47, 3769-3772.

[21] A. I. Nguyen, K. J. Blackmore, S. M. Carter, R. A. Zarkesh, A. F. Heyduk, J. Am. Chem. Soc. 2009, 131, 3307-3316.

[22] D. E. Herbert, N. C. Lara, T. Agapie, Chem. Eur. J. 2013, 19, 16453-16460.

[23] A. Nakamura, T. Yoshida, M. Cowie, S. Otsuka, J. A. Ibers, J. Am. Chem. Soc. 1977, 99, 2108-2117.

[24] S. Gambarotta, C. Floriani, A. Chiesi-Villa, C. Guastini, J. Am. Chem. Soc. 1982, 104, 1918-1924.

[25] J. L. Polse, A. W. Kaplan, R. A. Andersen, R. G. Bergman, J. Am. Chem. Soc. 1998, 120, 6316-6328.

[26] A. W. Kaplan, J. L. Polse, G. E. Ball, R. A. Andersen, R. G. Bergman, J. Am. Chem. Soc. 1998, 120, 11649-11662.

[27] T. Schaub, U. Radius, Z. Anorg. Allg. Chem. 2007, 633, 2168-2172.

[28] V. M. Iluc, G. L. Hillhouse, J. Am. Chem. Soc. 2014, 136, 6479-6488.

[29] For a more complete discussion of diazoalkane binding motifs, see: G. L. Hillhouse, B. L. Haymore, J. Am. Chem. Soc. 1982, 104, 1537-1548.

[30] W. A. Nugent, J. M. Mayer, Metal-Ligand Multiple Bonds, John Wiley \& Sons, New York, 1988.

[31] D. E. Wigley, Prog. Inorg. Chem. 1994, 42, 239-482.

[32] S. Cenini, E. Gallo, A. Caselli, F. Ragaini, S. Fantauzzi, C. Piangiolino, Coord. Chem. Rev. 2006, 250, 1234-1253.

[33] R. Waterman, G. L. Hillhouse, J. Am. Chem. Soc. 2003, 125, 13350-13351.

[34] P. Müller, C. Fruit, Chem. Rev. 2003, 103, 2905-2920.

[35] Y. M. Badiei, A. Dinescu, X. Dai, R. M. Palomino, F. W. Heinemann, T. R. Cundari, T. H. Warren, Angew. Chem. Int. Ed. 2008, 47, 9961-9964.

[36] N. D. Harrold, R. Waterman, G. L. Hillhouse, T. R. Cundari, J. Am. Chem. Soc. 2009, 131, 12872-12873.

[37] E. R. King, E. T. Hennessy, T. A. Betley, J. Am. Chem. Soc. 2011, 133, 4917-4923.

[38] M. G. Fickes, W. M. Davis, C. C. Cummins, J. Am. Chem. Soc. 1995, 117, 6384-6385.

[39] G. Proulx, R. G. Bergman, J. Am. Chem. Soc. 1995, 117, 6382-6383.

[40] G. Proulx, R. G. Bergman, Organometallics 1996, 15, 684-692.

[41] T. A. Hanna, A. M. Baranger, R. G. Bergman, Angew. Chem. Int. Ed. 1996, 35, 653-655.

[42] G. Guillemot, E. Solari, C. Floriani, C. Rizzoli, Organometallics 2001, 20, 607-615. 
[43] M. Barz, E. Herdtweck, W. R. Thiel, Angew. Chem. Int. Ed. 1998, 37, 2262-2265.

[44] H. V. R. Dias, S. A. Polach, S.-K. Goh, E. F. Archibong, D. S. Marynick, Inorg. Chem. 2000, 39, 3894-3901.

[45] G. Albertin, S. Antoniutti, D. Baldan, J. s. Castro, S. García-Fontán, Inorg. Chem. 2008, 47, 742-748.

[46] A. B. Pangborn, M. A. Giardello, R. H. Grubbs, R. K. Rosen, F. J. Timmers, Organometallics 1996, 15, 1518-1520.

[47] J. Miller, J. Org. Chem. 1959, 24, 560-561.

[48] P. A. S. Smith, C. D. Rowe, L. B. Bruner, J. Org. Chem. 1969, 34, 3430-3433.

[49] J. A. Miller, Tetrahedron Lett. 1975, 16, 2959-2960.

[50] B. C. Ranu, A. Sarkar, R. Chakraborty, J. Org. Chem. 1994, 59, 4114-4116.

[51] A. J. Arduengo III, R. Krafczyk, R. Schmutzler, H. A. Craig, J. R. Goerlich, W. J. Marshall, M. Unverzagt, Tetrahedron 1999, 55, 14523-14534.

[52] S. P. Nolan. U.S. Patent 7109348, 2006.

[53] V. Ritleng, E. Brenner, M. J. Chetcuti, J. Chem. Educ. 2008, 85, 1646.

[54] L. Jafarpour, E. D. Stevens, S. P. Nolan, J. Organomet. Chem. 2000, 606, 49-54.

[55] A. J. Arduengo III, S. F. Gamper, J. C. Calabrese, F. Davidson, J. Am. Chem. Soc. 1994, 116, 4391-4394.

[56] SMART; Bruker-AXS: Madison, WI, 2009.

[57] G. M. Sheldrick, Acta Cryst. 2008, A64, 112-122.

[58] O. V. Dolomanov, L. J. Bourhis, R. J. Gildea, J. A. K. Howard, H. Puschmann, J. Appl. Cryst. 2009, 42, 339-341.

[59] SADABS; Bruker-AXS: Madison, WI, 2012.

[60] http://www.cryst.chem.uu.nl/platon/.

[61] T. Dröge, F. Glorius, Angew. Chem. Int. Ed. 2010, 49, 6940-6952.

[62] J. Louie, J. E. Gibby, M. V. Farnworth, T. N. Tekavec, J. Am. Chem. Soc. 2002, 124, 15188-15189.

[63] K. Matsubara, K. Ueno, Y. Shibata, Organometallics 2006, 25, 3422-3427.

[64] K. Matsubara, S. Miyazaki, Y. Koga, Y. Nibu, T. Hashimura, T. Matsumoto, Organometallics 2008, 27, 6020-6024.

[65] A. A. Danopoulos, D. Pugh, Dalton Trans. 2008, 30-31.

[66] A. C. Hillier, W. J. Sommer, B. S. Yong, J. L. Petersen, L. Cavallo, S. P. Nolan, Organometallics 2003, 22, 4322-4326.

[67] H. Clavier, S. P. Nolan, Chem. Commun. 2010, 46, 841-861.

[68] D. J. Mindiola, G. L. Hillhouse, J. Am. Chem. Soc. 2001, 123, 4623-4624.

[69] A. Hammerl, T. Klapotke, in Encyclopedia of Inorganic Chemistry, 2nd ed. (Ed.: R. King), Wiley \& Sons, Chichester, 2005.

[70] F. H. Allen, O. Kennard, D. G. Watson, L. Brammer, A. G. Orpen, R. Taylor, J. Chem. Soc., Perkin Trans. 2 1987, S1-S19.

[71] M. I. Javed, M. Brewer, Org. Synth. 2008, 85, 189.

[72] R. Cohen, B. Rybtchinski, M. Gandelman, H. Rozenberg, J. M. L. Martin, D. Milstein, J. Am. Chem. Soc. 2003, 125, 6532-6546.

[73] V. K. Singh, A. DattaGupta, G. Sekar, Synthesis 1997, 1997, 137-149.

[74] X. Dai, T. H. Warren, J. Am. Chem. Soc. 2004, 126, 10085-10094.

[75] H. Pellissier, Tetrahedron 2008, 64, 7041-7095.

[76] D. Intrieri, A. Caselli, E. Gallo, Eur. J. Inorg. Chem. 2011, 2011, 5071-5081. 
[77] K. H. Dötz, Angew. Chem. Int. Ed. 1984, 23, 587-608.

[78] M. P. Doyle, in Comprehensive Organometallic Chemistry II (Ed.: E. W. A. G. A. S. Wilkinson), Elsevier, Oxford, 1995, pp. 387-420.

[79] W. D. Wulff, in Comprehensive Organometallic Chemistry II (Ed.: E. W. A. G. A. S. Wilkinson), Elsevier, Oxford, 1995, pp. 469-547.

[80] D. F. Harvey, D. M. Sigano, Chem. Rev. 1996, 96, 271-288.

[81] D. S. Wulfman, R. S. McDaniel Jr, B. W. Peace, Tetrahedron 1976, 32, 1241-1249.

[82] X. Huang, S. Klimczyk, L. F. Veiros, N. Maulide, Chem. Sci. 2013, 4, 1105-1110.

[83] A. J. Anciaux, A. J. Hubert, A. F. Noels, N. Petiniot, P. Teyssie, J. Org. Chem. 1980, 45, 695-702.

[84] T. Schaub, U. Radius, Chem. Eur. J. 2005, 11, 5024-5030.

[85] C. Rodríguez-García, A. Oliva, R. M. Ortuño, V. Branchadell, J. Am. Chem. Soc. 2001, 123, 6157-6163.

[86] J. M. Hopkins, M. Bowdridge, K. N. Robertson, T. S. Cameron, H. A. Jenkins, J. A. C. Clyburne, J. Org. Chem. 2001, 66, 5713-5716.

[87] R. Waterman, G. L. Hillhouse, J. Am. Chem. Soc. 2008, 130, 12628-12629.

[88] N. D. Harrold, G. L. Hillhouse, Chem. Sci. 2013, 4, 4011-4015.

[89] I. Bach, K.-R. Pörschke, R. Goddard, C. Kopiske, C. Krüger, A. Rufinska, K. Seevogel, Organometallics 1996, 15, 4959-4966. 